\title{
Loss of outer membrane integrity in Gram-negative bacteria by silver nanoparticles loaded with Camellia sinensis leaf phytochemicals: plausible mechanism of bacterial cell disintegration
}

\author{
M SINGH* ${ }^{\mathbb{D}}$, A K MALLICK ${ }^{\#}$ M BANERJEE ${ }^{\#}$ and R KUMAR \\ Department of Biotechnology, Haldia Institute of Technology, HIT Campus, Haldia 721657, India
}

MS received 20 January 2016; accepted 20 April 2016

\begin{abstract}
New generation antimicrobial and smart drugs are the needs of the present era in fighting microbial infection and various chronic diseases. Nowadays nanoparticles (NPs) are widely applied in biomedical fields by virtue of their surface modification, which enhances both target selectivity and function. This study is a continuation of our earlier study that demonstrated antimicrobial property of NPs against both Gram-positive and Gramnegative organisms (Goswami et al, 2015). Silver NPs were synthesized using tea leaves (Camellia sinensis) decoction and were characterized using UV-vis spectrophotometry, transmission electron microscopy (TEM) and Fouriertransformed infrared spectroscopy (FTIR). The silver NPs were stable at various environmental conditions. The stability of the particles may be due to various phytochemicals of tea that were bound to the surface of reduced silver ions as a capping agent. The antimicrobial activity of NP was investigated against three Gram-negative pathogenic bacteria (Shigella dysentriae, Salmonella infestis and Vibrio parahaemolyticus). The outer membrane of Gram-negative bacteria is a lipopolysaccharide (LPS) in nature and provides protection from various stress conditions and antibiotics. But a silver NP destroys its membrane integrity and thus helps in cell killing. Spectral changes confirmed NP interaction with hydrophobic moiety of LPS. Minimum inhibitory concentrations for S. dysentriae, $S$. infestis and $V$. parahaemolyticus were $3.75,5.25$ and $5.25 \mu \mathrm{g} \mathrm{ml}^{-1}$, respectively. Inhibition of biofilm formation was significant with the three bacterial strains. Cytoplasmic leakage from each bacterial strain was also demonstrated on account of NP treatment. The particles demonstrated good biocompatibility. No damage of human buccal mucosal cells was recorded even at concentration of $10 \mathrm{mg} \mathrm{ml}^{-1}$. Thus, silver NPs would be potential oral therapeutic molecules against Gram-negative bacteria.
\end{abstract}

Keywords. Antibacterial; biofilm; cytoplasmic materials leakage; membrane damage; silver nanoparticles; tea extract.

\section{Introduction}

Gram-negative bacteria have outer and inner cell membrane, though the thickness of the membrane is less than that of Gram-positive bacteria. The outer membrane is lipopolysaccharides (LPSs) in nature where the lipid portion acts as an endotoxin [1]. Small hydrophobic solutes can pass through the outer membrane (porin), but this membrane serves as a penetration barrier towards macro-molecules and to hydrophobic compounds, due to which Gram-negative bacteria are resistant towards hydrophobic antibiotics and toxic drugs. LPS is amphipathic in nature with hydrophobic tails protruding outside and hydrophobic lipids buried in the membrane. The inner membrane or cell wall of Gramnegative bacteria is protected from surrounding stressful environment (antibiotics, dyes, detergents, etc.) by the outer membrane Since decades, several important antibiotics are discovered and are being used though their efficacies are

\footnotetext{
\# AKM, MB and RK contributed equally to this study.

*Author for correspondence (msinghmukesh@gmail.com, singhmukesh@hithaldia.in)
}

decreasing presently, due to rise of multiple drug-resistant (MDR) strains [2-4]. The importance and increasing incidence of infections caused by Gram-negative bacteria have been pointed out by several investigators but infections caused by these microorganisms have received less attention than those due to other highly potent pathogenic bacteria like Staphylococci [5].

It has been reported that silver nanoparticles (NPs) have strong cytotoxic and antimicrobial property against a wide range of bacteria, fungi and viruses since decades. The importance of using silver NPs as antimicrobial molecules is due to less toxicity towards mammalian cells and higher toxicity to microorganisms [5]. It has been hypothesized that silver NPs can cause cell lysis or inhibit cell signal transduction [6]. The electrostatic attraction between positively charged NP and negatively charged bacterial cells is an important characteristic with respect to antimicrobial activity of NPs [7]. Attachment of NP with LPS on outer cell membrane causes structural changes in the cell membrane, modifying the permeability of the cell membrane and results in the death of the cell either by immediate lysis or by disturbing cellular metabolism. The NPs, compared with metal/metallic 
oxides, additionally enhance many of the properties because of the increases in surface area and surface to volume ratio [8]. Stress signals are sensed by the membrane-bound signal transduction system in bacteria [9]. Hence, targeting the membrane integrity is a crucial strategy of an antimicrobial drug development. Therapeutic molecules having potential to damage membrane may thus be used as an antimicrobial drug even for bacteria causing persistent infection. In contrast, Sondi and Salopek-Sondi [6] reported that the antimicrobial activity of silver NP on Gram-negative bacteria was dependent on the concentration of silver NPs, and was closely associated with the formation of pits in the cell wall of bacteria. It was suggested that metal depletion may cause the formation of irregularly shaped pits in the outer membrane and change membrane permeability, which is caused by progressive release of LPS molecules and membrane proteins [10].

Tea, the most popular beverage, was discovered by Shen Nung, the second emperor of China, in 2700 BC [11]. This beverage is associated with abundant health benefits. It has been reported that tea has physiological and pharmacological effects on human beings, which include strengthening capillaries, anti-inflammatory effects [12], lowering the risk of stroke, cancer and hypertension, enhancing immune function and preventing dental cavities and gingivitis [13-15]. Tea also exhibits intestinal protection by inhibiting growth of food-borne pathogenic bacteria [16]. All these health benefits resulted in extensive phytochemical studies of tea. The phytochemicals are presently being used in cosmetics and therapeutic preparations. The phytochemicals even helped many researchers to synthesize eco-friendly and biocompatible nanomaterials. The advantages of using tea phytochemicals in the field of nanotechnology are dual; both reducing and stabilizing agents are present in tea extracts. The watersoluble tea phytochemicals are catechins, theaflavins and thearubigins. The antimicrobial property [17] of tea phytochemicals is due to catechin gallates intercalating into phospholipid bilayers and perturbing the function of key processes associated with the bacterial cytoplasmic membrane. This interaction of phytochemicals with silver NP enhances the efficacy of antimicrobial action on Gram bacteria.

Looking into the beneficial uses of tea phytochemicals and increase of nanomaterials in the biological domain, here the antibacterial and antibiofilm activity of the silver NP colloidal suspension against three Gram-negative bacteria (Shigella dysentriae, Salmonella infestis and Vibrio parahaemolyticus) was investigated. Interaction of silver NPs with bacterial surface biomolecules was studied spectrophotometrically. Further, cellular leakage owing to NP was studied to confirm loss of outer membrane integrity in bacteria. Lastly, biocompatibility was tested against human buccal mucosal cells.

\section{Materials and methods}

\subsection{Materials}

Silver nitrate $\left(\mathrm{AgNO}_{3},>99.9 \%\right.$ pure $)$ was purchased from Sigma Aldrich; 2, 3, 5-triphenyl tetrazolium chloride (TTC), antibiotics discs and all other reagents were purchased from Himedia, India. Tea (Camelia sinensis) leaf powder was purchased from Castle Vintage Darjeeling Tea, Goodricke Group Ltd, Kolkata. All reagents used were of analytical grade. The bacterial viability experiments were carried out on Gram-negative ( $S$. dysentriae, S. infestis and V. parahaemolyticus) bacterial strains.

\subsection{Synthesis and characterization of silver NP}

Biogenic silver NP was synthesized as described by Goswami et al [18]. Tea leaf extract was prepared by taking $10 \mathrm{~g}$ of thoroughly washed leaves in a $250 \mathrm{ml}$ flask with $100 \mathrm{ml}$ of sterile distilled water and then boiling the mixture for $2 \mathrm{~min}$ before finally filtering it through Whatman No. 1 filter paper. The extract was stored at $4^{\circ} \mathrm{C}$ till further use. Silver NPs were synthesized according to standard reported methods. The reduction of pure silver ion $\left(\mathrm{Ag}^{+}\right)$into silver $\left(\mathrm{Ag}^{0}\right)$ was monitored by measuring the $\mathrm{UV}$-vis spectrum of the reaction medium (sample) by a Shimadzu UV spectrophotometer (PharmaSpac, UV-1700) using a quartz cell (1 cm path). The transmission electron microscopy (TEM) study was carried out in a JEOL, JEM 2100 electron microscope, operating at an acceleration voltage of $200 \mathrm{kV}$. NP suspension was thoroughly sonicated before TEM analysis. A Fourier-transformed infrared spectroscopy (FTIR) Shimadzu (IR Prestige 21) spectrometer with a KBr beam splitter was used to ascertain the involvement of bioactive component in NP synthesis. The NP was subjected to centrifugation at $9000 \mathrm{rpm}$ for $1 \mathrm{~h}$ and then the pellet was dissolved in appropriate volume of deionized double distilled sterile water, to remove free organic components from the NP suspension. The FTIR spectra of synthesized NP were recorded at a resolution of $4 \mathrm{~cm}^{-1}$ in the wavenumber region of $400-4000 \mathrm{~cm}^{-1}$.

\subsection{Antimicrobial efficacy of the silver NP}

In vitro antimicrobial activity of the NP colloid was screened against three Gram-negative bacterial strains, namely $S$. dysentriae, V. parahaemolyticus and S. infestis. Bacterial strains stock cultures were maintained at $4^{\circ} \mathrm{C}$ on a nutrient agar medium. Active cultures were prepared by inoculating a fresh nutrient broth medium with a loopful of cells from the stock cultures at $37^{\circ} \mathrm{C}$ overnight. To get desirable cell counts for bioassays, overnight grown bacterial cells were sub-cultured in a fresh nutrient broth at $37^{\circ} \mathrm{C}$.

Minimum inhibitory concentrations of NP against the bacterial strains were determined using the growth indicator tetrazolium/formazan test (TTC) according to Mshana et al [19]. In the presence of viable bacteria, TTC is reduced to red formazan and thus the change from colourless to red colour indicates the viability of the bacterial cells. All bacterial strains were grown in $10 \mathrm{ml}$ of LB with shaking at $225 \mathrm{rpm}$ overnight $\left(37^{\circ} \mathrm{C}\right)$. To each well, $100 \mu \mathrm{l}\left(1 \times 10^{5}\right.$ cells $\left.\mathrm{ml}^{-1}\right)$ of bacterial suspension was added and then $100 \mu \mathrm{l}$ of different concentrations of NP $\left(0-100 \mu \mathrm{g} \mathrm{ml}^{-1}\right)$ was transferred 
into a well of microplate. The final volume of each well of microplate was adjusted to $1 \mathrm{ml}$ by $\mathrm{LB}$ medium. The microplates were incubated at $37^{\circ} \mathrm{C}$ overnight. In each well, $25 \mu \mathrm{l}$ of sterile TTC $\left(5 \mathrm{mg} \mathrm{ml}^{-1}\right)$ was put and then the microplates were incubated at $37^{\circ} \mathrm{C}$ again. After overnight incubation, the minimum inhibitory concentration (MIC) of NP against the isolates was determined by observing the colour change in each well. The concentrations at which no change of colour occur indicate complete cell death.

\subsection{Biofilm assay}

Attenuation of biofilm formation by our pathogenic bacterial strains was determined using a polystyrene safranin adherence assay. In brief, a flat-bottomed polystyrene multiplate (12 wells) was used for biofilms eradication study. Each well containing $1 \mathrm{ml}$ of nutrient broth was inoculated with the respective bacterial strain with an inoculum of $1 \times 10^{5}$ cells ml $\mathrm{m}^{-1}$ and incubated for $72 \mathrm{~h}$ at $37^{\circ} \mathrm{C}$ supplemented with and without NP (4 and $\left.8 \mu \mathrm{g} \mathrm{ml}^{-1}\right)$. The biofilm that had grown over the surfaces of each well of the multiwall plate was used for evaluating inhibition of biofilm formation caused by synthesized NP. The biofilm formations at different concentrations of NP were visualized under a microscope (OLYMPUS IX 51, fitted with an Evolution VF CCD Camera). The safranin (1\%) retained within the biofilm was extracted by adding $100 \mathrm{ml}$ of $10 \%$ isopropyl alcohol (vol/vol) and absorbance measured at $490 \mathrm{~nm}$.

\subsection{Cytoplasmic leakage analysis}

Cytoplasmic materials were released from cells of all the bacteria, namely $S$. dysentriae, S. infestis, V. parahaemolyticus and $S$. aureus, because of NP treatment and were time dependent for protein and DNA. For cytoplasmic material release study, bacterial cells from each pathogenic strain were harvested from $10 \mathrm{ml}$ of bacterial culture by centrifugation at low speed and the pellet was washed with PBS buffer (1x, pH 7.2). Next, the pellet was suspended in $1 \mathrm{ml}$ of PBS buffer and cell number was adjusted to $1 \times$ $10^{5}$ cells $\mathrm{ml}^{-1}$. Different aliquots of cell suspensions were treated with and without $\mathrm{NP}\left(\mathrm{MIC}_{50}\right)$ and incubated at room temperature for different time periods $(0,1,3,4$ and $7 \mathrm{~h})$. The samples were centrifuged to remove bacteria cells, and absorbance values of supernatants were recorded at $260 \mathrm{~nm}$ for nucleic acid release, and Lowry's method [20] was followed for estimation of protein leakage. Determination of $\beta$-galactosidase activity was based on the hydrolysis of the substrate ortho-nitrophenyl- $\beta$-D-galatopyranoside to the yellow product ortho-nitrophenol and $\beta$-D galactose. Orthonitrophenol was spectroscopically quantified at $420 \mathrm{~nm}$. The amount of cytoplasmic material release was recorded by subtracting the OD values obtained from cells without treatment and was compared to OD values of Triton X-100 treatment (positive control) to get cytoplasmic leakage index. The experiment was repeated three times.

\subsection{Silver NP and protein, polysaccharides and lipid interaction}

To study the interaction of silver NP with protein, sucrose and lipid, an absorption study was performed. Our objective was to check how NP interacts with biomolecules present on/in the cell membrane of Gram-negative bacteria. Test solutions of protein (BSA), polysaccharides (starch) and lipids (Tween 20) were prepared by adding calculated amount in known volume of buffer solution and studied further.

\subsection{Test for biocompatibility}

Human buccal mucosal cells were treated with varying concentrations of NP to test for biocompatibility on human cells. The toxicity test was necessary to designate NP for human applications. For the collection of buccal mucosa cells, the ethical committee of Haldia Institute of Technology approved the research plan. Healthy patients were selected as donors who had no history of smoking, obesity and chronic and metabolic diseases. Initially donors were asked to wash the mouth twice with mineral water. Sterile wooden scalpels were used to collect buccal cells by gently scraping 10 times the inside of both cheeks and dispersing the cells by dipping the scalpel into falcon tubes containing $10 \mathrm{ml}$ of saline solution. The cell suspension was centrifuged at $8000 \mathrm{~g}$ for $10 \mathrm{~min}$ at $4^{\circ} \mathrm{C}$. After centrifugation, the supernatant was discarded and cells were suspended in a saline solution. Equal volume of cell suspension was used for NP treatment. NP in the range of $1-10 \mathrm{mg} \mathrm{ml}^{-1}$ was added to cell suspension in $1.5 \mathrm{ml}$ Eppendorf tubes and was incubated at $37^{\circ} \mathrm{C}$ for $4 \mathrm{~h}$. The effect on buccal mucosa cells at different concentrations of NP was visualized under a microscope (OLYMPUS IX 51, fitted with the Evolution VF CCD Camera). Next, to check leakage of DNA and protein from cells due to membrane damage, NP-treated cell suspension was centrifuged at $7000 \mathrm{~g}$ for $10 \mathrm{~min}$ at $4^{\circ} \mathrm{C}$. After completion of centrifugation, supernatants from each set were transferred to fresh tubes and designated as the supernatant fraction. The presence of the DNA was confirmed by spectroscopic absorbance values of supernatants, which were recorded at $260 \mathrm{~nm}$, and Lowry's method [20] was followed for estimation of protein leakage.

\subsection{Statistical analysis}

The data presented in this dissertation are represented as the mean with standard deviation (mean \pm standard deviation). The statistical significance was calculated by one-way analysis of variance (ANOVA) using SPSS software (IBM SPSS Statistics Standard) and the level of significance was compared at $* P \leq 0.05$. Each experiment was replicated at least three times.

\section{Results and discussion}

\subsection{Synthesis and characterization}

Our previous communication [18] describes the synthesis and detailed characterization of silver NPs produced by 
reduction of the silver ions by a decoction of semi-fermented leaves of tea. To further extend the applicability of this silver NP which was used as an antibiofilm agent against $S$. aureus and $E$. coli in our previous report, we used it to investigate the action against Gram-negative bacteria in this study.

The synthesized NP was kept for 6 months at room temperature and was further characterized by UV-vis spectroscopy and FTIR. Figure 1a shows the UV-vis spectrum recorded from the aqueous silver nitrate-tea leaf extract reaction medium. The figure exhibits that the surface plasmon resonance $(\mathrm{SPR})$ band of silver appears at $416 \mathrm{~nm}$. The absorbance spectra also indicate the particles average size to be $35 \mathrm{~nm}$ [21,22]. The colourless aqueous silver nitrate solution became brown after overnight incubation at $37^{\circ} \mathrm{C}$ with tea aqueous extract (inset of figure 1a). It is well known that this change in colour of the silver NPs occurs because of the surface plasmon vibration in the NPs [23]. Representative TEM images of sample are shown in figure $1 \mathrm{~b}$. The TEM micrograph revealed that the particles were spherical in shape. The selected area electron diffraction (SAED) pattern (inset ii of figure 1b) with bright spots indicates that the silver NPs are crystalline in nature. A single NP image is shown in inset $\mathrm{i}$ of figure $1 \mathrm{~b}$. There was no sign of any precipitation in the colloidal suspension. The reason behind the high stability of this NP may be due to the extract of tea leaf that contains phenolic compounds, proteins and carbohydrates. The proteins and polysaccharides biomolecules are reported to have stabilizing property [24]. Proteins and carbohydrates form electrostatic capping with silver NPs. FTIR studies of the freeze-dried samples were carried out to identify the possible interactions between silver and phytochemicals of tea leaf extract, which may be responsible for synthesis and stabilization (by capping material) of silver NPs. The major peaks of variable intensity present in the sample 6 months back in our previous study were also recorded at the same wavelengths with no significant changes. The important peaks were located at about 650, 726, 1043, 1147, 1292, 1375, 1431, 1647, 2926 and $3376 \mathrm{~cm}^{-1}$ (figure 2). The FTIR spectrum reveals a band at $1647 \mathrm{~cm}^{-1}$ that corresponds to the bending vibrations of the amide band of the proteins and corresponding stretching vibration was seen at $2926 \mathrm{~cm}^{-1}$. The two bands observed at 1375 and $1043 \mathrm{~cm}^{-1}$ may be assigned to the $\mathrm{C}-\mathrm{N}$ stretching vibrations of the aromatic and aliphatic amines, respectively. The peak at $1147 \mathrm{~cm}^{-1}$ is due to $\mathrm{C}-\mathrm{O}-\mathrm{C}$ stretching of polysaccharides. These observations indicate the presence of polyphenols, leading to the reduction of silver nitrate to silver NPs, since polyphenols are reported to be strong reducing agents.

\subsection{Susceptibility of Gram-negative bacteria towards silver NP}

Silver NPs are widely known for their antimicrobial property against Gram-positive and Gram-negative bacteria. The antimicrobial activity of our synthesized NPs was demonstrated to be highly positive against $S$. aureus and $E$. coli in our previous study. In the present study, pathogenic Gramnegative bacterial strains were tested against our synthesized NPs. The NPs exhibited inhibitory response against the tested bacterial strains in a dose-dependent manner. It was more active against $S$. dysentriaea compared with $V$. parahaemolyticus and S. infestis. MIC for S. dysentriae, S. infestis and V. parahaemolyticus was $3.75,5.25$ and $5.25 \mu \mathrm{g} \mathrm{ml} \mathrm{m}^{-1}$, respectively.

\subsection{Effect of silver NP on biofilm formation}

The biofilm assay was based on the ability of bacteria to form biofilm on solid polystyrene surface. Biofilm formation is an important strategy for bacterial virulence and survival. The eradication of biofilm is an important criterion for the development of new generation antibacterial compounds.

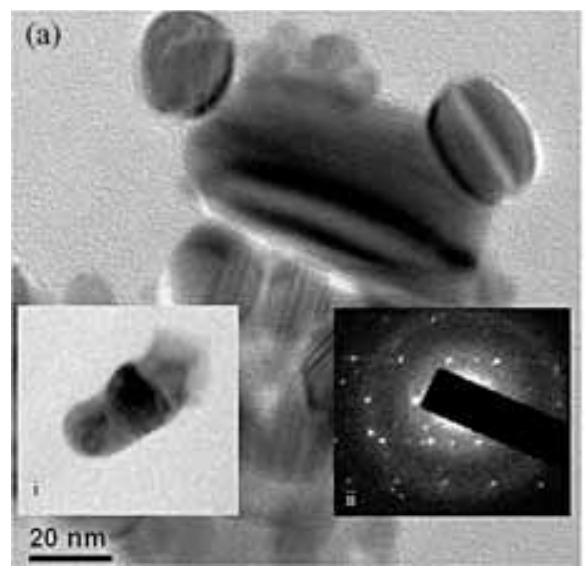

(b)

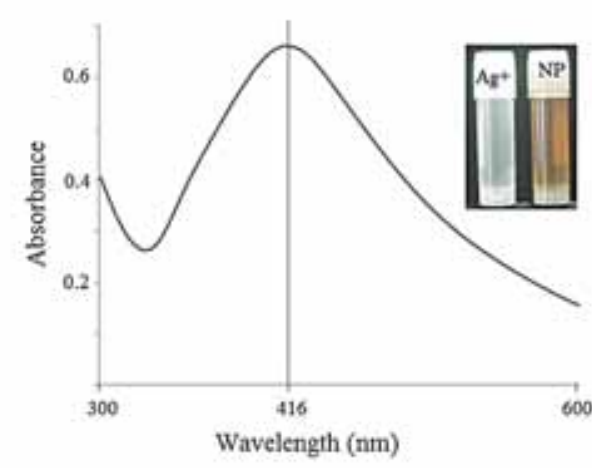

Figure 1. Characterization of bio-fabricated silver nanoparticles. (a) UV-vis spectra of aqueous solution of NPs. The inset depicts colour change observed in the reaction mixture containing tea aqueous extract and $1 \mathrm{mM}$ silver nitrate after overnight incubation at $37^{\circ} \mathrm{C}$ with continuous shaking. (b) TEM image of NPs illustrating the high-resolution image. The insets i and ii display the single NP and SAED patterns. 


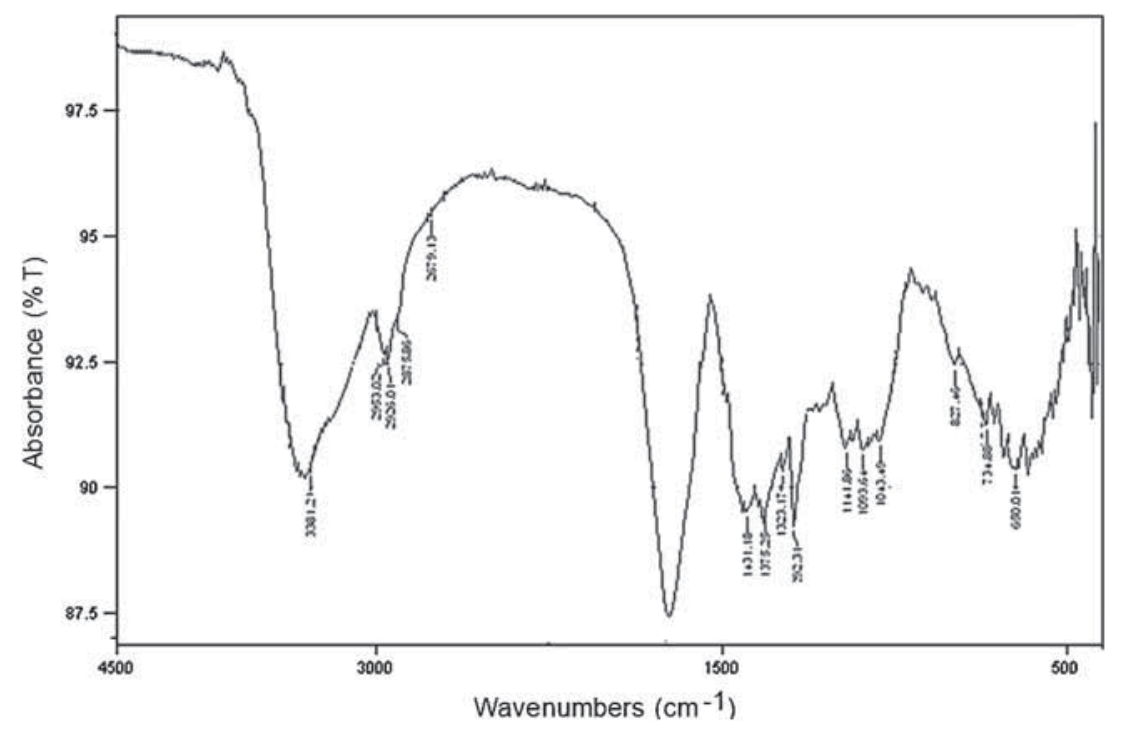

Figure 2. FTIR spectrum of silver nanoparticles stabilizes with tea decoction recorded as a $\mathrm{KBr}$ pellet at a resolution $4 \mathrm{~cm}^{-1}$.

Table 1. Biofilm growth percentage of bacterial strains on solid support when exposed to silver nanoparticles for $72 \mathrm{~h}$.

\begin{tabular}{lccc}
\hline & & \multicolumn{2}{c}{$\mathrm{NPs}\left(\mu \mathrm{g} \mathrm{ml}{ }^{-1}\right)$} \\
\cline { 3 - 4 } Bacteria & Control & 2 & 4 \\
\hline Shigella dysentriaea, & 100 & $64.4 \pm 1.06^{*}$ & $28.2 \pm 0.076^{*}$ \\
Salmonella infestis & 100 & $83.6 \pm 0.74$ & $64.7 \pm 0.98^{*}$ \\
Vibrio parahemolyticus & 100 & $75.5 \pm 1.12$ & $37.5 \pm 1.09^{*}$ \\
\hline
\end{tabular}

Data are expressed as mean (percentage) \pm standard deviation.

The data exhibit statistically significant differences between control and treated sets $(* P \leq 0.05)$.

Bacterial cellular properties such as hydrophobicity help in cell to cell adherence and thus help in formation of biofilm. Hence any damage to the cell envelope can hinder its ability to adhere to each other and subsequently inhibits biofilm formation. In this context, the ability of NP in eradicating biofilm formation was analysed. All the three tested strains were used to develop their biofilm over the polystyrene surface of the well of microtitre plate and removal efficiency of NP was checked by spectrophotometry and light microscopy. Supplementary figure S1 illustrates the biofilm removal ability of NPs against the tested bacterial strains. Results of light microscopy and safranin absorbance measured at $490 \mathrm{~nm}$ showed significant removal of biofilm formation with NP concentration of 2 and $4 \mu \mathrm{g} \mathrm{ml}^{-1}$ (Supplementary figure S1 and table 1). The biofilm eradication activity was the highest at $4 \mu \mathrm{g} \mathrm{ml}^{-1}$ and was statistically significant $(P \leq 0.05)$ for all bacterial strains. The eradication efficiency was also statistically significant at $2 \mu \mathrm{g} \mathrm{ml}^{-1}$ of NPs only in $S$. dysentriae. The result indicates that eradication activity of NPs after 3 days of treatment for $S$. dysentriae was more pronounced, followed by $V$. parahaemolyticus and S. infestis. It may be postulated that cell-cell adhesion present on the solid surface was weakened due to NPs penetration inside the biofilms. Biomaterials used in human prosthetics are susceptible to infection by various micro-organisms as observed worldwide [25]. Valappil along with his co-worker [26] and many researchers across the globe had reported role of silver NPs in prevention of biofilms from biomaterials, which confirmed our results, though percentage of eradication is higher in our study, compared with most of the reported literature. The synthesized NPs can be used as a disinfectant for hospital and domestic purpose.

\subsection{Quantification of cytoplasmic leakage of protein and DNA contents}

Silver NPs disturb the membrane integrity of pathogenic bacteria as reported earlier by many researchers. To gain more insight into the effects of this molecule, we quantified the amounts of cytoplasmic material (DNA and protein) that were released by the microbes. A comparison of external DNA and protein contents in the supernatants of NPtreated $\left(\mathrm{MIC}_{50}\right)$ and untreated bacterial cells in PBS buffer was performed using spectroscopic analysis. The results of this experiment indicated that NPs indeed caused loss of intracellular material from resting cells of all bacteria tested. Study of released protein and DNA contents in the supernatant of NP-treated bacterial cells was profound for different time points $(0,1,3,5$ and $7 \mathrm{~h})$ as compared with control set of all bacteria. The results are shown in figure 3 . There were statistically significant $(P \leq 0.05)$ differences of DNA released between the bacteria for different time points. Amount released is the highest in $S$. dysentriae followed by those of $V$. parahemolyticus and $S$. infestis. Increase of DNA content in the supernatant incubated up to $5 \mathrm{~h}$ was noticed for all the tested bacteria, followed by significant decrease. Nuclease activity in the PBS buffer release because of cell damage may degrade the excess DNA present in the 


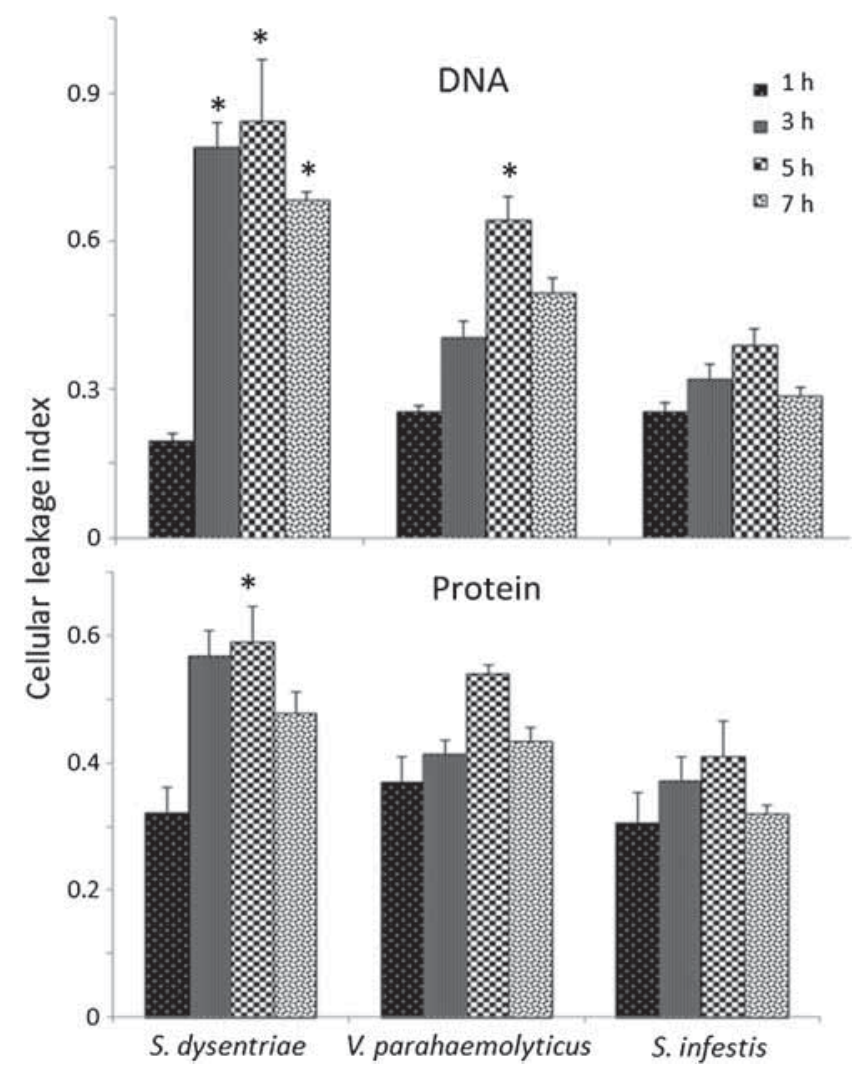

Figure 3. Bacterial cellular leakage (DNA and protein) due to silver NPs treatment at different time points $(1,3,5$ and $7 \mathrm{~h})$ in PBS buffer at room temperature. Releases of intracellular materials were monitored by spectrophotometry. The amount of cytoplasmic material release was recorded by subtracting the OD values obtained from cells without treatment and was compared to OD values of Triton X-100 treatment (positive control) to get cytoplasmic leakage index.

supernatant with increasing incubation time. A significant increase of DNA content in the supernatant of NP-treated cells clearly demonstrates the formation of a large hole in the bacterial membrane, since DNA is a sterically complex large molecule. For protein quantification, Lowry's method was employed to estimate the amount of protein released in the supernatant because of NPs treatment of bacterial cells. Increase of protein content in the supernatant was seen up to $5 \mathrm{~h}$; beyond this time point there was decrease in the amount of protein content (figure 3). Decrease of protein content was due to release of proteolytic enzyme after membrane damage that degrades the protein. The leakage of intracellular material upon exposure of susceptible bacteria to an antibacterial drug often has been invoked as evidence of membrane-damaging action. It was observed that $S$. dysentriae demonstrated statistically significant $(P \leq 0.05)$ DNA leakage for all time points tested whereas results of leakage in case of S. infestis were not significant. Protein leakage was recorded for all bacteria tested but was not statistically significant $(P \leq$ 0.05 ) except the result of $5 \mathrm{~h}$ incubation in $S$. dysentriae, which was significant. Hotchkiss [27] was the first to demonstrate that leakage of nitrogen- and phosphorous-containing

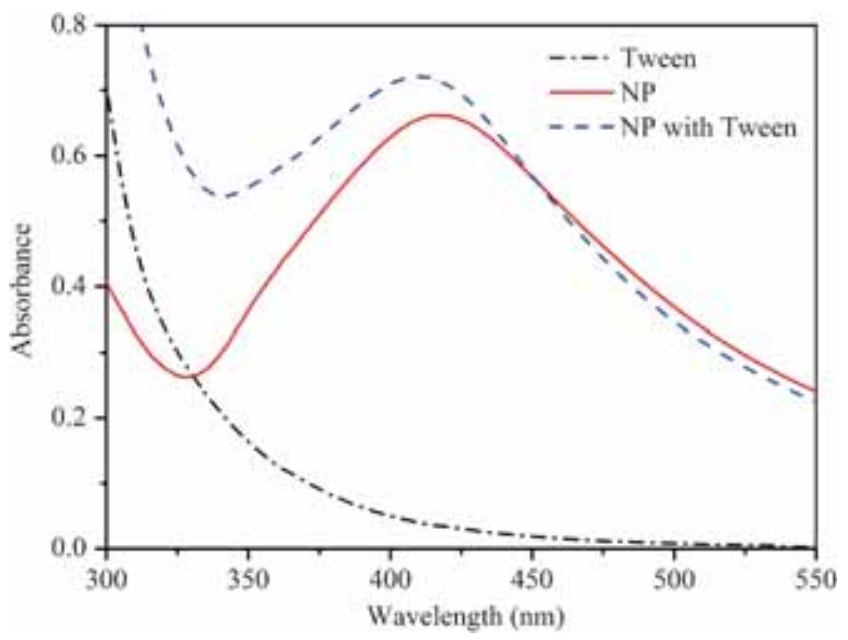

Figure 4. Peak shift of silver nanoparticles in the presence and the absence of Tween 20.

compounds takes place from germicide-treated staphylococci. Extending the finding of Hotchkiss, Salton proved that the released materials contain substances that absorb light at 260 nm, i.e., DNA [28].

\subsection{Silver NP and protein, polysaccharides and lipid interaction}

The absorbance maximum of synthesized NPs as exhibited by UV-vis spectroscopy measurement is $416 \mathrm{~nm}$. Figure 4 presents the change of absorbance of NP in the presence of lipid (here Tween 20). The change in spectral behaviour of NPs after interaction with Tween 20 indicates the plausible causes for loss of membrane potential in bacterial cell. There were no significant shifts in absorbance behaviour in the presence of sucrose and BSA (data not shown). The reason behind negligible shift in spectral behaviour might be the concentration used for the interaction in the present studies.

\subsection{Test for biocompatibility}

Buccal epithelial cells bioassay is considered as a reliable tool for toxicants screening. These cells are directly exposed to chemicals in food, drugs and the environmental pollutant, making them the candidate cell type to check the effects of various toxicants. Simultaneously, isolation and application for bioassays of buccal mucosa cells is very simple [19]. Thus use of buccal cell offers advantages in addressing the toxicological issue of NPs. An in vitro assay was studied to find out whether the synthesized NP discriminates between buccal epithelial cells and microbes. Assay with $\mathrm{NP}$ in the concentration range of $1-10 \mathrm{mg} \mathrm{ml}^{-1}$ was evaluated. There was no loss of membrane integrity of buccal cells even at $10 \mathrm{mg} \mathrm{ml}^{-1}$ of NP concentrations, which was evidenced by absence of DNA and protein in the soup collected after separation of buccal cells. The MIC values, which were in the range of $3-5 \mathrm{mg} \mathrm{ml}^{-1}$, did not show noticeable 


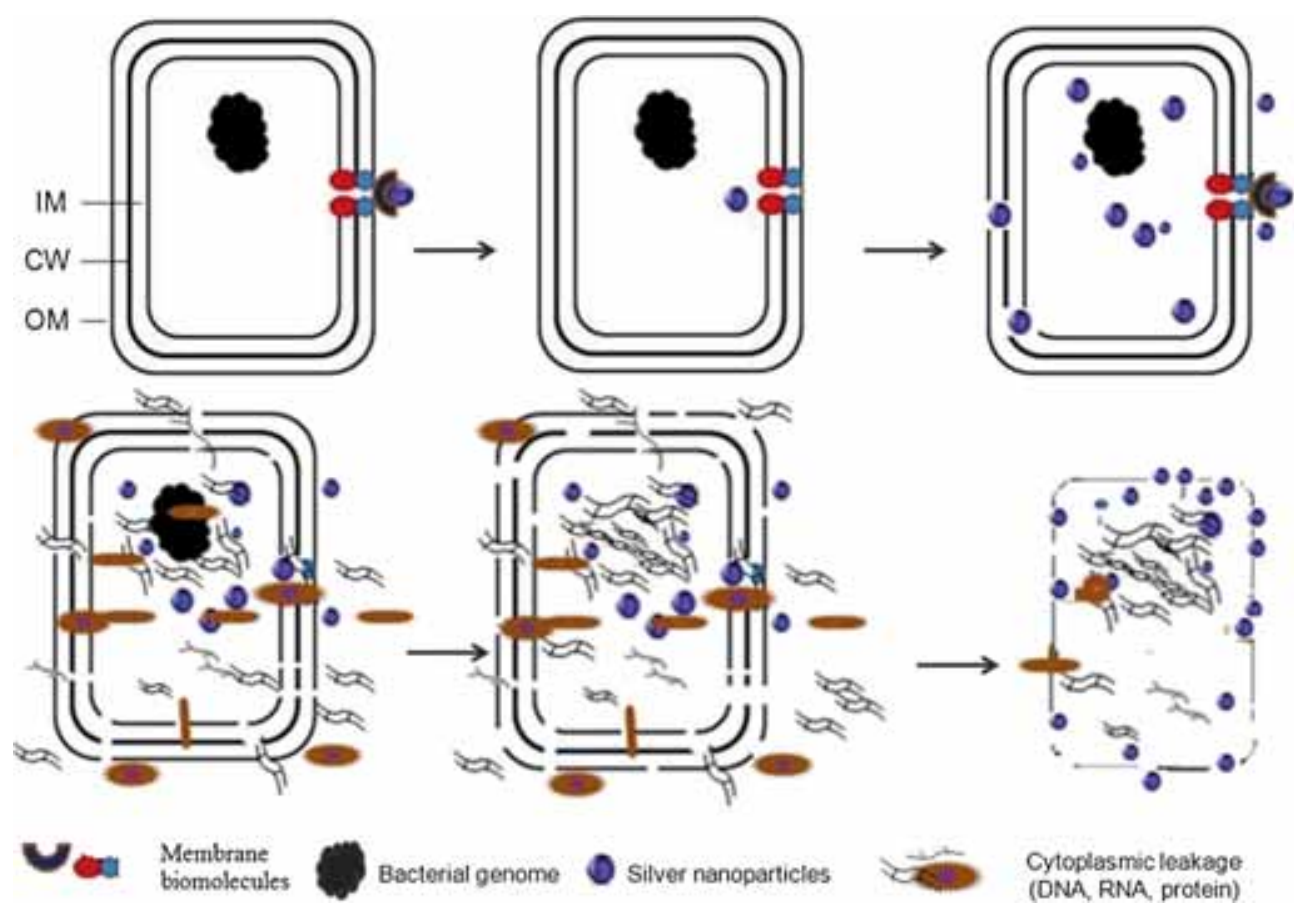

Figure 5. Cartoon representation of cytotoxic action of silver nanoparticles towards bacterial cell.

damage to buccal epithelial cells (result not shown). In our earlier report, the NP demonstrated insignificant damage to goat blood [18]. Thus, the cell viability/integrity was not conciliated and no acute toxicity was observed.

\section{Conclusion}

In this study, silver NP synthesized using tea decoction showed potential antimicrobial activity. The phytochemicals of tea not only kept the NPs stable but helped in enhancing their antimicrobial activity. The three tested bacteria exhibited susceptibility towards NPs. Antibiofilm activity was also noted significantly. Cytoplasmic leakage confirms creation of holes in the membrane by silver NPs. Figure 5 demonstrates mechanism of bacterial killing by our silver NPs. Disturbance of cell membrane causes pores through which cellular materials (DNA and protein) leakage takes place. Furthermore, ROS generation inside the cell takes place that affects gene expression and even fragmentation of genomic DNA. Finally cell lysis occurs due to pores on the cell membrane, loss of metabolic activity and cellular leakage.

Since surface active molecules and membrane-disrupting compounds are crucial in the field of antimicrobial chemotherapy, our bio-compatible synthesized silver NPs may prove their potential in this field.

\section{Electronic supplementary material}

Supplementary material pertaining to this article is available on the Bulletin of Materials Science website (www.ias.ac.in/ matersci).

\section{Acknowledgements}

We are thankful to the Department of Biotechnology, Haldia Institute of Technology, for providing necessary facilities to carry out the experiment of this work.

\section{References}

[1] Nikaido H 1996 Outer membrane, in: Neidhardt F C (eds) Escherichia coli and Salmonella: cellular and molecular biology (Washington, DC: ASM Press) vol 1 p 29

[2] Andersson D I and Hughes D 2010 Nat. Rev. Microbiol. 8260

[3] Bridier A, Briandet R, Thomas V and Dubois-Brissonnet F 2011 Biofouling 271017

[4] Borgesa A, Serra S, Abreu A C, Saavedra M J, Salgado A and Simões M 2014 Biofouling 30183

[5] Li W R, Xie X B, Shi Q S, Zeng H Y, Ou-Yang Y S and Chen Y B 2010 Appl. Microbiol. Biotechnol. 851115

[6] Sondi I and Salopek-Sondi B 2004 J. Colloid Interface Sci. 275177

[7] Hamouda T, Myc A, Donovan B, Shih A, Reuter J D and Baker J R 2000 Microbiol. Res. 1561

[8] Baker C, Pradhan A, Pakstis L, Pochan D J and Shah S I 2005 J. Nanosci. Nanotechnol. 5244

[9] Reck M, Rutz K, Kunze B, Tomasch J, Surapaneni S K, Schulz S and Wagner-Dobler I 2011 J. Bact. 1935692

[10] Amro N A, Kotra L P, Wadu-Mesthrige K, Bulychev A, Mobashery S and Liu G 2000 Langmuir 162789

[11] McKay D L and Blumberg J B 2002 J. Am. Coll. Nutr. 211

[12] Min Z and Paige X 1991 Pyrometer. Res. 5239

[13] Fraser M L, Mok G S and Lee A H 2007 Complement. Ther. Med. 1546 
[14] Thangapazham R L, Singh A K, Sharma A, Warren J, Gaddipati J P and Maheshwari R K 2007 Cancer Lett. 245232

[15] Satish K N, Nripen C, Ravi S, Kavita K, Rajesh R K, Subramanian T, Swapna M, Raghuraman K and Kattesh V K 2009 J. Mater. Chem. 192912

[16] Keller A, Tiffany L W, Corey D B and Ryan E P 2013 Food Res. Int. $\mathbf{5 3} 945$

[17] Olosunde O F, Abu-Saeed K and Abu-Saeed M B 2012 Adv. Pharm. Bull. 2259

[18] Goswami S R, Sahareen T, Singh M and Kumar S 2015 J. Ind. Eng. Chem. 2673

[19] Mshana R N, Tadesse G, Abate G and Miörner H 1998 J. Clin. Microbiol. 361214

[20] Lowry O H, Rosebrough N J, Farr A L and Randall R J 1951 J. Biol. Chem. 193265
[21] Li W R, Xie X B, Shi Q S, Zeng H Y, Ou-Yang Y S and Chen Y B 2010 Appl. Microbiol. Biotechnol. 85 1115

[22] Lubick N 2008 Environ. Sci. Technol. 428617

[23] Sau K, Rogach A L, Jäckel F, Klar T A and Feld-mann J 2010 Adv. Mater. 221805

[24] Vaidyanathan R, Kalishwaralal K, Gopalram S and Gurunathan S 2009 Biotechnol. Adv. 27924

[25] Schierholz J M, Beuth J, Rump A, König D P and Pulverer G J 2001 J. Chemother. 1239

[26] Valappil S P, Pickup D M, Carroll D L, Hope C K, Pratten J, Newport R J et al 2007 Antimicrob. Agents Chemother. 514453

[27] Hotchkiss R D 1946 Ann. N. Y. Acad. Sci. 46479

[28] Salton M R J and Gen J 1951 J. Gen. Microbiol. 5391 